\title{
Seroprevalence and intercurrence of reproductive pathogens in cattle from family farms in North of Minas Gerais, Brazil
}

\section{Soroprevalência e intercorrência de patógenos reprodutivos em bovinos da agricultura familiar no Norte de Minas Gerais, Brasil}

\author{
Dionei Joaquim Haas ${ }^{1}$; Jonata de Melo Barbieri ${ }^{1}$; Ermilton Junio Pereira de \\ Freitas $^{1}$; Mayra da Silva Oliveira ${ }^{1}$; Bernardo Rodrigues Porto ${ }^{2}$; Rogério Oliveira \\ Rodrigues $^{3}$; Marcos Bryan Heinemann ${ }^{4}$; Anna Christina de Almeida ${ }^{5}$; Zélia Inês \\ Portela Lobato ${ }^{6}$; Elaine Maria Seles Dorneles ${ }^{7}$; Andrey Pereira Lage ${ }^{6 *}$
}

\begin{abstract}
The aims of the present study were: to estimate the seroprevalence of Bluetongue virus (BTV), bovine alphaherpesvirus 1 (BoHV-1), bovine viral diarrhea virus (BVDV), Brucella abortus and Leptospira spp. in cattle from family farms in North of Minas Gerais; to determine the intercurrence and association among these pathogens; and to assess the possible associated factors to seropositive herds and animals. For this, 476 cows from 46 farms were sampled and evaluated serologically. The seroprevalence in herds and cattle was, respectively, for BTV $100 \%$ and $52.0 \%$, for BoHV-1 $95.7 \%$ and $48.6 \%$, for BVDV $78.3 \%$ and $46.1 \%$, for Leptospira spp. $76.1 \%$ and $29.1 \%$, and for B. abortus was $0 \%$ in herd and cattle. More than $65 \%$ of the herds was simultaneously seropositive for BTV, BoHV-1, BVDV and Leptospira spp. Seropositivity for BoHV-1, Leptospira spp. serovar Autumnalis and serovar Hardjoprajitno were associated with abortion, whereas seropositivity for BVDV was associated with BoHV-1. Moreover, association among seropositivity for BVDV, BoHV-1 and Leptospira spp. was also observed. In conclusion, BTV, BoHV-1, BVDV and Leptospira spp. are highly seroprevalent and occurred simultaneously in cattle from family farms in Minas Gerais, indicating the need for the implementation of control measures to avoid economic losses related to these diseases.
\end{abstract}

Key words: Bluetongue. Bovine brucellosis. Bovine reproductive diseases. Bovine viral diarrhea. Infectious bovine rhinotracheitis. Leptospirosis.

\section{Resumo}

Os objetivos do presente estudo foram: $i$ ) estimar a soroprevalência de Bluetongue virus (BTV), bovine alphaherpesvirus 1 (BoHV-1), bovine viral diarrhea virus (BVDV), Brucella abortus e Leptospira spp. em bovinos da agricultura familiar no Norte de Minas Gerais, Brasil; ii) determinar a intercorrência e

\footnotetext{
' Discentes, Universidade Federal de Minas Gerais, UFMG, Belo Horizonte, MG, Brasil. E-mail: dioneihaas@hotmail.com; jonata_melobarbieri@hotmail.com; ermilton_medvet@yahoo.com.br; mayraoliveira@msn.com

2 Discente, UFMG, Montes Claros, MG, Brasil. E-mail: Bernardo.Porto@br.nestle.com

3 Pesquisador, Instituto de Pesquisas Veterinárias Desidério Finamor, IPVDF, Eldorado do Sul, RS, Brasil. E-mail: rogerrodriguesvet@gmail.com

4 Prof., Universidade de São Paulo, USP, São Paulo, SP, Brasil. E-mail: marcosbryan@usp.br

5 Prof ${ }^{a}$, UFMG, Montes Claros, MG, Brasil. E-mail: aca2006@ica.ufmg.br

6 Profs., UFMG, Belo Horizonte, MG, Brasil. E-mail: ziplobat@vet.ufmg.br; alage@vet.ufmg.br

Prof ${ }^{a}$, Universidade Federal de Lavras, UFLA, Lavras, MG, Brasil. E-mail: selesdorneles@yahoo.com.br

Author for correspondence
} 
associação entre esses patógenos; iii) e avaliar os possíveis fatores associados aos rebanhos e animais soropositivos. Para isso, 476 vacas de 46 fazendas foram amostradas e avaliadas sorologicamente. A soroprevalência de rebanhos e animais foi, respectivamente, para BTV de $100 \%$ e 52.0\%, para BoHV1 de $95.7 \%$ e $48.6 \%$, para BVDV de $78.3 \%$ e $46.1 \%$, para Leptospira spp. de $76.1 \%$ e $29.1 \%$ e para B. abortus de $0 \%$ para ambos rebanhos e bovinos. Mais de $65 \%$ dos rebanhos foram simultaneamente soropositivos para BTV, BoHV-1, BVDV e Leptospira spp. A soropositividade para BoHV-1, Leptospira spp. sorovar Autumnalis e sorovar Hardjoprajitno foram fatores associados com aborto, enquanto soropositividade para BVDV foi fator associado com BoHV-1. Além disso, associação entre a soropositividade para BVDV, BoHV-1 e Leptospira spp. foi observada. Em conclusão, BTV, BVDV, BoHV-1 e Leptospira spp. são altamente soroprevalentes e ocorrem simultaneamente em bovinos da agricultura familiar de Minas Gerais, indicando a necessidade da implementação de medidas de controle para evitar perdas econômicas relacionadas a essas doenças.

Palavras-chave: Brucelose bovina. Diarreia viral bovina. Doenças reprodutivas bovinas. Leptospirose. Língua azul. Rinotraqueíte infecciosa bovina.

\section{Introduction}

Family farms are important for the Brazilian economy producing a large part of food consumed in the country, including meat and milk. This contribution is so representative, that in regions with a high number of family farms, such as the North region of Minas Gerais, $45 \%$ of the production of cattle milk comes from this type of farm (Empresa de Assistência Técnica e Extensão Rural de Minas Gerais [EMATER-MG], 2014; Instituto Brasileiro de Geografia e Estatística [IBGE], 2006). In Brazil, family farms are defined as properties that have less than four fiscal modules, in which the labor force used is predominantly from their own family and that have the income mainly from agricultural activity (IBGE, 2006). The fiscal module is the minimum area required for the farm to be economically viable and in Minas Gerais State it corresponds to up to 70 hectares.

Nevertheless, the number of studies that refer to the health aspects of cattle from this peculiar agricultural sector is scarce in Brazil. Knowledge of the sanitary status of the animals and herds is quite important in livestock, especially for diseases related to reproductive disorders. Reproductive failures, such as infertility, embryonic death, abortion, congenital malformation, the birth of weak calves and stillbirths, are responsible for low performance in dairy cattle production and cause great economic losses to cattle industry worldwide
(Sanderson \& Gnad, 2002). Studies estimate that in $90 \%$ of cases, in which an etiologic diagnosis is achieved, the abortions are due to infectious agents (Silva et al., 2009), being the major pathogens associated with reproductive losses in cattle are bovine alphaherpesvirus 1 (BoHV-1), bovine viral diarrhea virus (BVDV), Brucella abortus and Leptospira spp. (Cortez et al., 2006; Sanderson \& Gnad, 2002). Another possible agent associated with reproductive failure in cattle is Bluetongue virus (BTV) (Lobato, Guedes, \& Matos, 2015). Although cattle are commonly asymptomatic to BTV, virus infection may result in embryonic death, abortion, in stillbirths, the birth of weak calves, or the birth of calves with cerebral abnormalities (Lobato et al., 2015).

Studies carried out in Brazil have shown that BoHV-1, BTV, BVDV, B. abortus and Leptospira spp. are individually reported in cattle herds throughout the country (Cortez et al., 2006; Lobato et al., 2015; Richtzenhain et al., 1999a; Richtzenhain et al., 1999b), including Minas Gerais State (Araújo, Moreira, Naveda, Silva, \& Contreras, 2005; Castro et al., 1992; L. F. Oliveira et al., 2016). A few studies described the presence of these pathogens also in family farms from the States of Mato Grosso do Sul (Tomich et al., 2009), Paraíba (R. M. Oliveira et al., 2013), Pernambuco (Rêgo et al., 2016) and Rondônia (Okuda et al., 2006), however, the intercurrence of these five agents 
was not previously evaluated in this type of cattle raising system in Brazil. The determination of the prevalence of seropositive animals and herds, and the simultaneous occurrence of different infectious agents, besides the association between common risk factors and those infections or co-infections, can be very useful to optimize reproductive disease control programs in family farms.

Thus, the aims of this study were: $(i)$ to estimate the seroprevalence of BTV, BoHV-1, BVDV, $B$. abortus and Leptospira spp. in cattle from family farms in the North region of the state of Minas Gerais, (ii) to determine the intercurrence and associations among those infections in cattle and herds, (iii) and to assess the possible associated factors to seropositive herds and animals.

\section{Material and Methods}

Study area

The study area embraced the municipalities of Icaraí de Minas (16 $6^{\circ} 13^{\prime} 02^{\prime \prime S}$ and $\left.44^{\circ} 54^{\prime} 23^{\prime \prime} \mathrm{W}\right)$, Juramento (16 $6^{\circ} 50^{\prime} 53^{\prime \prime} \mathrm{S}$ and $\left.43^{\circ} 35^{\prime} 13^{\prime \prime} \mathrm{W}\right)$ and São

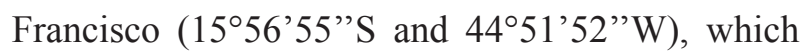
belong to the North mesoregion of Minas Gerais State, Brazil. The climate of the region is typically tropical, warm and semi-humid, with a short rainy season (November to March), followed by a long and dry one (April to October), being classified in the climatic class Aw, according to the Köppen-Geiger classification (Azevedo, Felix, Pires, Almeida, \& Duarte, 2011; Sá, Carvalho, Silva, \& Alves, 2012).

Agriculture is the predominant economic activity of the region, where $57.71 \%$ of the herds are beef farms, $27.51 \%$ are dairy farms and $14.76 \%$ are double-purpose production systems (beef and dairy). More than of $76.43 \%$ of the farms keep livestock in the extensive system, $23.24 \%$ in the semi-confined system and only $0.33 \%$ in the confined system. The cattle herds are predominantly small, with a median of 30 animals per farm (L. F. Oliveira, 2016; Alves et al., 2018). The main beef breeds are Zebu (Nellore and Gyr) and their crossbreeds. The predominantly used dairy breed in the region is the Holstein, followed by Gyr dairy and Girolando (Azevedo et al., 2011; Menezes et al., 2014).

\section{Study design}

A census of family farms of the Programa de Apoio a Agricultores Familiares do Norte de Minas Gerais em Atividades de Produção, Higiene e Saúde Pública - PROAF (Program of support to production activities, hygiene and public health for family farms from the North of Minas Gerais), an institutional program from Universidade Federal de Minas Gerais (UFMG), was performed in 2013. All 46 family farms participating in PROAF in 2013 were included.

\section{Sampling}

The sample size of animals included in the study was calculated to allow herd sensitivity and specificity to be equal to or greater than $95 \%$ for all the infectious agents assessed. Therefore, in each farm at least 10 animals were sampled, resulting in a total of 476 sampled animals. To avoid interference of vaccinal antibodies to brucellosis (Ministério da Agricultura, Pecuária e Abastecimento [MAPA], 2006), only cows aged 24 months or older were sampled. All sampled cows were vaccinated with $B$. abortus Strain 19 (B19) during calfhood (MAPA, 2006), but were not vaccinated against BoHV-1, BTV, BVDV and Leptospira spp.

This study was approved by the Ethics Committee in Animal Experimentation of the UFMG (CEUA Protocol no 145/2013).

\section{Serological tests}

Detection of antibodies anti-BTV was performed by the agar gel immunodiffusion assay (Pearson \& Jochim, 1979), with antigen produced 
and standardized as previously described (Costa, Lobato, Herrmann, Leite, \& Haddad, 2006).

Neutralizing antibodies against BoHV-1 and BVDV were assessed by the virus neutralization technique using Madin-Darby bovine kidney cell line (ATCC CCL-22), with viral strains BoHV-1 Colorado-1 (ATCC VR-864) and BVDV NADL (ATCC VR 534), respectively (World Organization for Animal Health [OIE], 2015, 2017). Serum with neutralizing antibody titer $\geq 4$ was considered positive (OIE, 2015, 2017).
Anti-Leptospira agglutinins were evaluated by the microscopic agglutination test (Cole, Sulzer, \& Pursell, 1973), using a battery of 16 different serovars (Table 1). Sera were tested in two-fold dilution from 1:100 until the final titer. Sera that showed $50 \%$ or more of agglutinated Leptospira spp. by the microscopic field in a certain dilution were considered positive. The infecting serovar, for herd or animal, was defined as the serovar that elicited the greater number of reactors in the specific farm or the higher agglutination titer for the animal, respectively (Vasconcellos et al., 1997).

Table 1

Serovars of Leptospira sp. used in the microscopic agglutination test for testing cattle from family farms in North of Minas Gerais, Brazil

\begin{tabular}{lll}
\hline Sorogrups & Serovar & Strain \\
\hline Australis & Australis & Ballico \\
Autumnalis & Autumnalis & Akiyami A \\
Bataviae & Bataviae & Van tienen \\
Ballum & Castellonis & Castellon 3 \\
Cellodoni & Celledoni & Celledoni \\
Grippotyphosa & Grippotyphosa & Moskva V \\
Hebdomadis & Hebdomadis & Hebdomadis \\
Icterohaemorragiae & Icterohaemorrhagie & RGA \\
Javainica & Javanica & Veldrat Batavia 46 \\
Mini & Szwajizak & Swajizak \\
Panama & Panama & CZ 214 K \\
Pomona & Pomona & Pomona \\
& & Hardjoprajitno \\
Sejroe & Hardjo & Norma \\
& & Lagoa* \\
& & Bolivia* \\
& Hardjobovis & Sponselee \\
Shermani & Sejroe & M 84 \\
\hline
\end{tabular}

* Leptospira interrogans serovar Hardjo genotype Hardjoprajitno strain isolated from Minas Gerais, Brazil (Chiareli et al., 2012).

Antibodies against B. abortus were screened by test (Tecpar, Brazil), as recommended by Programa the Rose Bengal plate agglutination test (Tecpar, Nacional de Controle e Erradicação de Brucelose e Brazil) and confirmed by the 2-mercaptoethanol Tuberculose Animal - PNCEBT (Nacional Program 
for the Control and Eradication of Brucellosis and Tuberculosis) from the Ministério da Agricultura, Pecuária e Abastecimento (Brazilian Ministry of Agriculture, Livestock and Food Supply) (MAPA, 2006).

\section{Statistical procedures}

Apparent prevalence, as well as the confidence interval (95\%), were calculated using the STATA $^{\circledR}$ 12 (StataCorp, USA) statistical software (Lewis \& Torgerson, 2012). Herd sensitivity and specificity for each disease was calculated using the package epiR (Stevenson et al., 2017) in the R software (R version 3.1.1, R Development Core Team, New Zealand). The herd was classified as positive for BTV, BoHV1 or B. abortus if at least one seropositive animal was found, and as positive for BVDV or Leptospira spp. if there were at least two seropositive animals in the farm, according to the sensitivity and specificity of their respective serological tests to result in herd sensitivity and specificity greater than $95 \%$ for all cases.

To determine the factors associated with the presence of antibodies against the studied pathogens, an epidemiological questionnaire was applied in all sampled herds. This questionnaire included questions on: 1) Farm characteristics - Type of husbandry; Farm activity; Milking type; Number of milkings per day; Rent pasture; Sharing pasture; Wetlands; Raising other species of domestic animals; Presence of wild animals; 2) Herd characteristics - Number of dairy cows; Total number of cattle; Breed of animals; 3) Production characteristics - Amount of milk produced; Milk destination; Milk cooling; Production of other dairy products and their destination; Consuming raw milk; 4) Characteristics of health management and reproductive - Breeding system; Report of abortion at the last year in the herd; Destination of placenta and aborted fetus; Brucellosis test; Transit of animals (sales and purchases); Vaccination against brucellosis; Place of animals Slaughter; Veterinary care; Presence of maternity pen; 5) Animal characteristics - Multiparous or primiparous cows; Report of abortion at the last year by animal; Report of repeat breeding at the last year by animal. Details on all variables in the questionnaire are showed in Table S1 (Supplementary material).

Initially, a univariate analysis was performed by the chi-square or Fisher's exact test (Zar, 1996) and the variables with $\mathrm{P} \leq 0.2$ (Zar, 1996) were selected for further analyses. The selected variables were submitted to multivariate logistic regression modeling, by a forward process to a final designbased model keeping variables with $\mathrm{P} \leq 0.05$ (Hosmer \& Lemeshow, 2000). Odds ratio and 95\% confidence interval were calculated. The serological results obtained by the diagnostic tests for the selected infectious agents were used as dependent variables, whereas variables from each animal or herd were modeled as independent variables.

Joint Correspondence Analysis, a multivariate technique for visualizing associations among a set of more than two variables (Greenacre, 2005), was used to study the association among BoHV-1, BTV, BVDV and Leptospira spp., at both animal and herd levels.

\section{Results}

The family farms evaluated in this study were predominantly dairy farms $(65.2 \%)$, using semiconfined breeding $(69.5 \%)$, with less than 20 cows in lactation per herd (71.1\%), mainly hand-milked $(73.9 \%)$ and producing up to 120 liters of milk / herd / day $(63.6 \%)$. The average area of farms was $97.3 \pm 54.1$ hectares. The average number of animals and females per herd was $79.9 \pm 58.6$ and $65.6 \pm 49.4$, respectively, with a median of 26 cows with more than 24 months per herd. More than $78 \%$ of the cattle had the phenotype of crossbred Bos taurus subsp. taurus, $8.6 \%$ had characteristics of crossbred Bos taurus subsp. indicus, while only $6.5 \%$ of the animals were considered pure Bos taurus subsp. taurus and $6.5 \%$ pure Bos taurus 
subsp. indicus. Most of the herds had no veterinary assistance (58.6\%), used natural breeding (71.7\%) and acquired animals for reproduction directly from other herds $(65.2 \%)$. Abortions were reported in $48 \%$ of the studied herds in the last year.

The overall seroprevalences for the studied pathogens are summarized in Table 2 and the distribution of co-infection among animals and herds is shown in Figure 1. BTV was the most seroprevalent among the agents investigated, at both herd and animal levels, followed by BoHV1, BVDV and Leptospira spp. The most prevalent anti-Leptospira spp. antibodies was against serovar Hardjo followed by serovars Australis, Autumnalis and Pomona. Strains Lagoa, Hardjoprajitno and Bolívia elicited most of the reactions for serovar Hardjo. B. abortus antibodies were not detected in any of the tested animal.

Seropositivity for at least two of the studied infectious agents was observed in all herds and approximately $65.2 \%$ (95\% CI: 50.9 - 79.5\%) of the studied herds showed, at the same time, cows seropositive to BoHV-1, BTV, BVDV and Leptospira spp. However, only 4.0\% (95\% CI: 2.4
$-6.1 \%$ ) of the cows tested were seropositive for all those agents simultaneously. Moreover, none of the studied herds showed all the tested animals seronegative for all the studied infectious agents. In addition, $57.8 \%$ (95\% CI: $52.9-62.1 \%$ ) of the cattle exhibited antibodies to more than one infectious agent and only $10.7 \%$ (95\% CI: $8.0-13.8 \%$ ) of cattle were seronegative for all tested pathogens (Figure 1).

Factors associated with infection by the studied agents are summarized in Table 3. BoHV-1 (P = 0.003), Leptospira spp. serovar Autumnalis ( $\mathrm{P}$ $=0.006)$ and Leptospira spp. serovar Hardjo $(\mathrm{P}=0.018)$ were associated with abortion, and seropositivity for BVDV $(\mathrm{P}=0.000)$ was associated with the presence of seropositive cows for BoHV-1.

In the correspondence analysis, BVDV, BoHV-1 and Leptospira spp. were associated at herd level, while at animal level, BVDV and BoHV-1 were associated (Figure 2). The variance explained by the first dimension of the model was $78.93 \%$ and $70.21 \%$ for herd and animal models, respectively, and that explained by the second dimension was $21.07 \%$ and $29.76 \%$ for herd and animal models, respectively. 


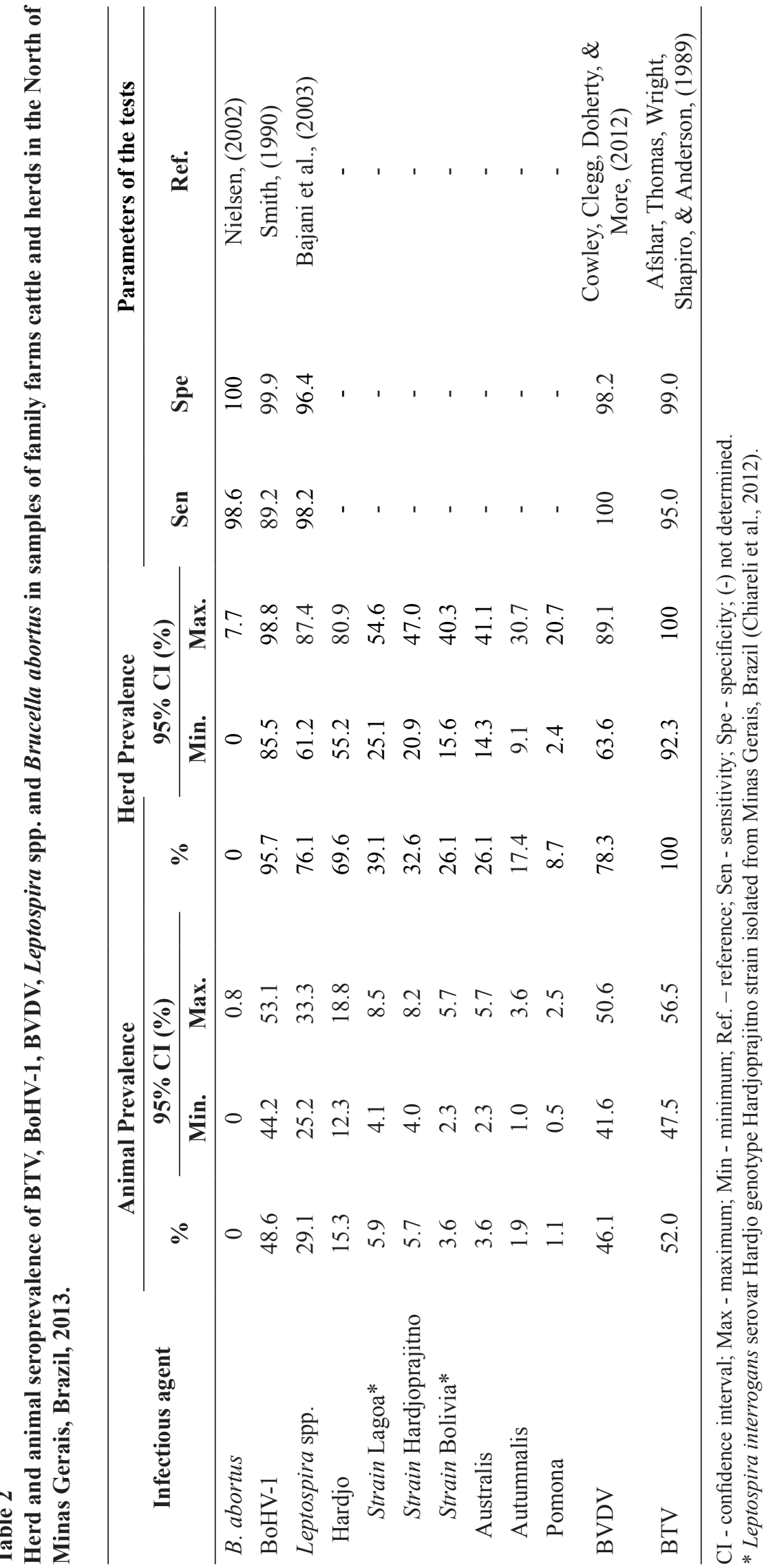




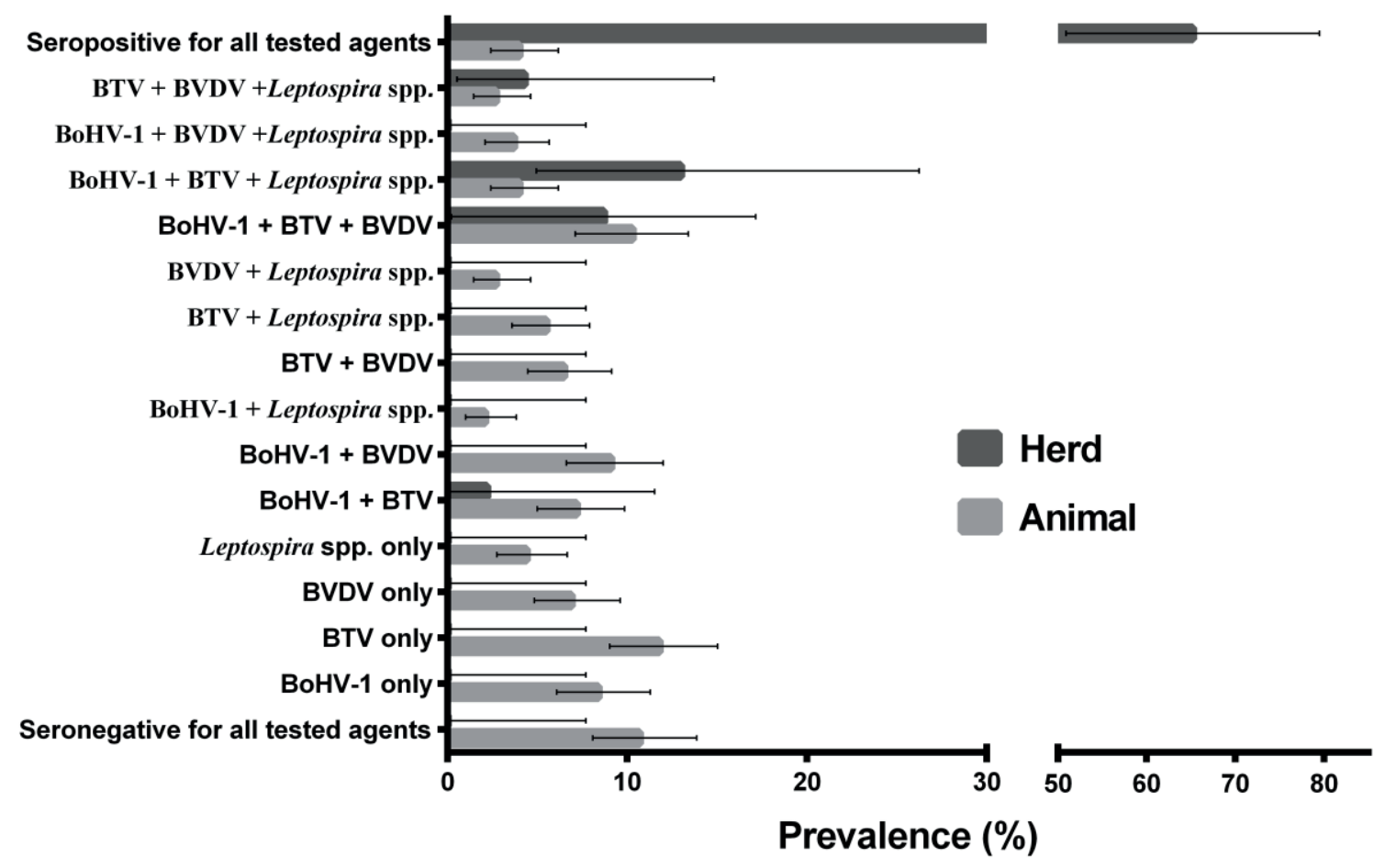

Figure 1. Animal and herd seroprevalence of BTV, BoHV - 1, BVDV and Leptospira spp. in family farms in the North Minas Gerais, Brazil, 2013.

Table 3

Multivariate logistic regression analysis using as model the variables report of abortion at the last year by animal and BoHV - 1 seropositivity in cattle from family farm in the North Minas Gerais, Brazil, 2013.

\begin{tabular}{clccccc}
\hline Model & Variable & $\beta$ & S.E. $(\beta)$ & OR & CI (95\%) & P-value \\
\hline \multirow{3}{*}{ BoHV - 1 } & Intercept & -0.3893 & 0.1297 & & & \\
& BVDV-positive animal & 0.7561 & 0.1896 & 2.13 & $1.47-3.10$ & 0.000 \\
& Intercept & -1.0461 & 0.1572 & & & \\
& $\begin{array}{l}\text { Leptospira interrogans serovar Hardjo } \\
\text { genotype Hardjoprajitino-positive animal }\end{array}$ & 0.9969 & 0.4219 & 2.71 & $1.18-6.19$ & 0.018 \\
Abortion & $\begin{array}{l}\text { Leptospira interrogans Autumnalis-posi- } \\
\text { tive animal }\end{array}$ & 2.2396 & 0.8168 & 9.39 & $1.89-46.59$ & 0.006 \\
& BoHV-1-positive animal & 0.6151 & 0.2085 & 1.85 & $1.23-2.79$ & 0.003 \\
\hline
\end{tabular}

$\mathrm{CI}$ - confidence interval; OR - odds ratio; $\mathrm{P}$ - value - probability value; SE $(\beta)$ - standard error; $\beta$ - coefficient. 


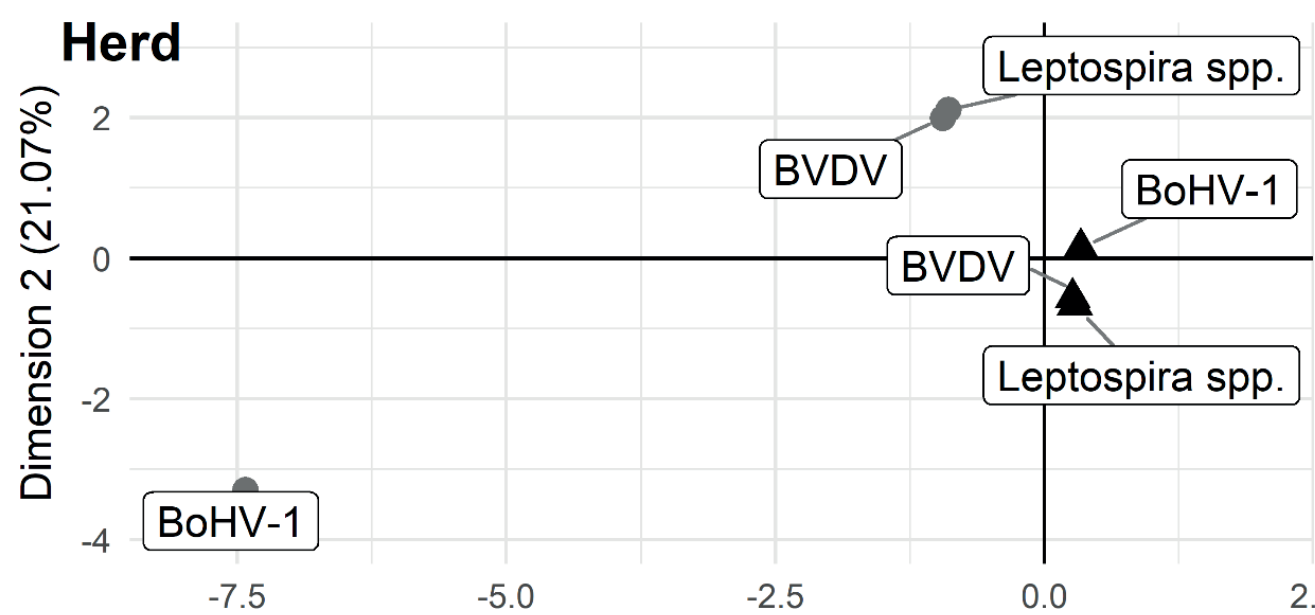

Dimension $1(78.93 \%)$

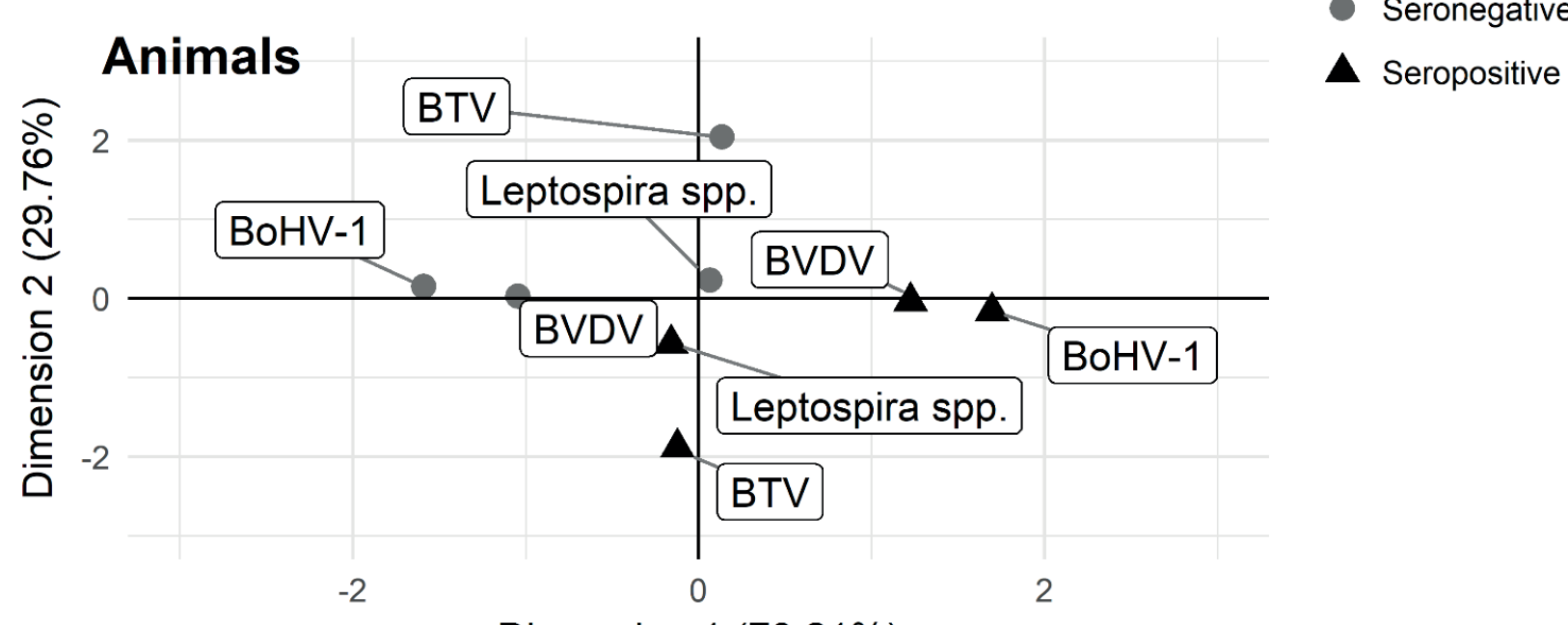

Dimension 1 (70.21\%)

Figure 2. Joint correspondence analysis for the occurrence of BoHV-1, Leptospira spp., BVDV and BTV antibodies in family farms cattle and herds in the North Minas Gerais, Brazil, 2013.

\section{Discussion}

The global seroprevalence for reproductive agents observed in the current study shows a disturbing health scenario, with high rates of seropositive cattle for BoHV-1, BTV, BVDV and Leptospira spp. in family farms from the North of Minas Gerais. These high seroprevalence for BoHV1, BTV, BVDV and Leptospira spp. found may be due to several factors, mainly to the low biosecurity and sanitary conditions observed in the studied farms. Acquisition of animals without performing diagnostic tests and absence of vaccination, common practices in family farms from the North of Minas
Gerais (Azevedo et al., 2011; Menezes et al., 2014), are known to benefit the spread and maintenance of reproductive infectious agents in cattle herds (Sanderson \& Gnad, 2002). The high seropositivity to these agents could also reflect our sampling strategy that included only cows over 24 months of age, which were in the reproductive age and often exhibit higher positivity rates when compared to young animals (Freitas et al., 2014; Thompson et al., 2006), since aging and reproduction increase the probability of exposure to the infectious agents studied. However, most meaningful, the studied population is the one that is in reproduction in the 
herd and, therefore, is the one that more severely affected by the consequences of the reproductive infections, such as decreasing fertility and abortion.

The high seroprevalence of Leptospira spp., mainly to serovar Hardjo, and the finding that $L$. interrogans serovar Hardjo genotype Hardjoprajitno was associated with abortion in the studied samples could be of great economic importance, as suggested by other investigations carried out in Minas Gerais (Araújo et al., 2005; Vasconcellos et al., 1997). Also important was the finding that most of the Leptospira spp. serovar Hardjo infected animals were detected using the strains Lagoa and Bolivia, isolated in Minas Gerais (Chiareli et al., 2012), which supports the use of local isolates of Leptospira spp. to increase the sensitivity of the diagnosis (Lage et al., 2007; Pinto, Loureiro, Penna, \& Lilenbaum, 2015). Moreover, these results confirm that the most important Leptospira spp. for cattle is serovar Hardjo, for which cattle is the main reservoir (Lage et al., 2007). Interestingly, our serological survey also showed that L. interrogans serovar Autumnalis, a serovar that has only been associated with incidental cattle infections (Pinto et al., 2015), was associated with abortion. L. interrogans serovar Autumnalis has as reservoirs rodents and dogs (Petrakovsky, Bianchi, Fisun, Nájera-Aguilar, \& Pereira, 2014), animals that usually have access to farms and cattle, and thereby could play a role in the epidemiology of bovine leptospirosis. However, the association of L. interrogans serovar Autumnalis and abortion in cattle in the region needs to be scrutinized in future investigations.

The high seropositivity found for BTV may be attributed to favorable climatic conditions in the study region, such as high temperature and rainfall, which favors the presence of Culicoides spp., the BTV vector (Laender, Ribeiro, Gouveia, Lobato, \& Felippe-Bauer, 2004). Those favorable conditions for the presence of the vector certainly play a crucial role in the dissemination and maintenance of BTV in the studied population. The main manifestation of
BTV in cattle is teratogenicity in the aborted fetuses (Lobato et al., 2015), however this information was not available from the sampled herds. Despite that, it is important to consider that BTV-infected cattle have a great epidemiological relevance, since they are important viral reservoirs for highly susceptible animals, such as sheep (Lobato et al., 2015), which were also present in the farms and the studied region (Laender et al., 2004).

The absence of brucellosis among the studied cattle is in accordance with the survey carried out in the Minas Gerais State in 2011, which estimated the brucellosis animal prevalence to be $0.7 \%(0 \%$ - $1.7 \%$ ) in cattle from the Northwest, North and Northeast regions of the State (L. F. Oliveira, 2016). Furthermore, the risk for brucellosis seropositivity was estimated to be low in Minas Gerais herds with a small number of cows (L. F. Oliveira, 2016), as in the studied population, which has a median of 26 cows with more than 24 months per herd. We must also consider that, the B19 compulsory vaccination practiced since the 1990s in Minas Gerais, certainly helped to enhance the herd immunity and to decrease the prevalence of brucellosis in Minas Gerais State (Ferreira et al., 2016). In fact, in Brazilian states where B19 vaccination program is more recent, as in Paraíba for example, the seroprevalence of brucellosis observed in family farms (R. M. Oliveira et al., 2013), as well as in the whole state cattle population (Ferreira et al., 2016) were higher than the one found in the present study.

The most important findings of this study, the high rate $(65.2 \%)$ of herds simultaneously seropositive for BTV, BoHV-1, BVDV and Leptospira spp. and the association among BVDV, BoHV-1 and Leptospira spp., revealed that concomitant seropositivity to multiple pathogens is a very frequent phenomenon in cattle herds. Importantly, these findings suggest that mixed infections could play a key role in the etiology of reproductive problems in the studied herds, since that seropositivity for BoHV-1, L. interrogans serovar Hardjo genotype Hardjoprajitno 
and L. interrogans Autumnalis were associated with abortion and abortions were reported in $48 \%$ $(22 / 46)$ of the studied herds in the last year. This concomitant seropositivity for multiple infectious agents can have a major impact on the reproductive performance of those females, due to the fact that cows with this serological status are at higher risk of reproductive problems, when compared to cows seropositive for a single agent or seronegative (Biuk-Rudan, Cvetníc, Madić, \& Rudan, 1999). Therefore, the findings of the present study suggest that an association among these three pathogens have a central role in reproductive disorders in the studied family farms.

The association found among BVDV, BoHV-1 and Leptospira spp. serological status could be, at least in part, result of shared transmission routes among the three agents, as the natural breeding, which is the predominant reproductive strategy in the studied farms. Furthermore, since concurrent seropositivity can make an individual either more susceptible or resistance to future infectious diseases by influencing host immune responses to pathogens (Candela et al., 2009; Nikbakht et al., 2015), the association found may also be result of the pathobiology of one of the three agents involved in co-infection. Indeed, the immunosuppressive nature of BVDV infection (Bolin, 2002; Potgieter, 1995 ) and the fact that BVDV seropositivity was associated with BoHV-1 seropositivity suggest that BVDV may be the trigger of this association. The acute BVDV infection causes transient immunosuppression, promoting severe reduction in number and function of lymphocytes, granulocytes and monocytes in cattle (Brewoo, Haase, Sharp, \& Schultz, 2007), enhancing the vulnerability to various agents, among them BoHV-1 and Leptospira spp. (Bolin, 2002; Brewoo et al., 2007).

Hence, considering that BVDV can predispose to infection by BoHV-1 and Leptospira spp., the elimination of BVDV-positive cattle seems to be important to control the three diseases in the studied herds. Furthermore, the use of artificial insemination, polyvalent vaccines, transit control for animals and the implementation of biosecurity measures for replacement cattle are also indicated, as they will help to simultaneously control these important reproductive diseases in the region.

\section{Conclusions}

In conclusion, the reproductive pathogens BTV, BoHV-1, BVDV and Leptospira spp., but not $B$. abortus, were highly seroprevalent in cattle herds of family farms from North of Minas Gerais. A large number of farms exhibited seropositive animals to various pathogens, with high intercurrence of BTV, BoHV-1, BVDV and Leptospira spp. L. interrogans serovar Hardjo, L. interrogans serovar Autumnalis and BoHV-1 were associated with abortion. Infection by BVDV, BoHV-1 and Leptospira spp. were associated, whereas BVDV-seropositivity was associated with seropositivity for BoHV-1. All those findings could help to improve the strategies for controlling these diseases in this livestock production system.

\section{Acknowledgements}

The authors are grateful to G.C.F. Galinari, A.M. Leite and E. Nogueira, for their technical assistance. This study was supported by: Conselho Nacional de Desenvolvimento Científico e Tecnológico (CNPq), Fundação de Amparo à Pesquisa do Estado de Minas Gerais (Fapemig) and Fundação de Apoio ao Ensino, Pesquisa e Extensão (FEPE). DJH, EJPF, JMB, MSO and EMSD are indebet to Coordenação de Aperfeiçoamento de Pessoal de Nível Superior (CAPES) for their scholarships. APL and $\mathrm{MBH}$ thank CNPq for their fellowships. APL was also supported by the Programa Pesquisador Mineiro - PPM (00923-15), from Fapemig. ACA acknowledges support from the Fapemig and MEC/ PROExt/SESu. 


\section{References}

Afshar, A., Thomas, F. C., Wright, P. F., Shapiro, J. L., \& Anderson, J. (1989). Comparison of competitive ELISA, indirect ELISA and standard AGID tests for detecting bluetongue virus antibodies in cattle and sheep. The Veterinary Record, 124(6), 136-141. doi: 10.1136/vr.124.6.136

Alves, C. D. M., Dorneles, E. M. S., Oliveira, L. F., Ferreira, J. S., Neto, Gonçalves, V. S. P., Lobo, J. R.,... Lage, A. P. (2018). Productive profile of cattlerearing farms in the state of Minas Gerais, Brazil, 2002. Brazilian Journal of Veterinary Research and Animal Science, 55(4), 1-14. e143933-e143933. doi: 10.11606/issn.1678-4456.bjvras.2018.143933

Araújo, V. E. M., Moreira, E. C., Naveda, L. A. B., Silva, J. A., \& Contreras, R. L. (2005). Frequência de aglutininas anti-Leptospira interrogans em soros sanguíneos de bovinos, em Minas Gerais, de 1980 a 2002. Arquivo Brasileiro de Medicina Veterinária e Zootecnia, 57(1), 430-435. doi: 10.1590/S010209352005000400002

Azevedo, R. A. de, Felix, T. M., Pires, O. de S., Jr., Almeida, A. C. de, \& Duarte, E. R. (2011). Perfil de propriedades leiteiras ou com produção mista no Norte de Minas Gerais. Revista Caatinga, 24(1), 153-159.

Bajani, M. D., Ashford, D. A., Bragg, S. L., Woods, C. W., Aye, T., Spiegel, R. A.,... Weyant, R. S. (2003). Evaluation of four commercially available rapid serologic tests for diagnosis of leptospirosis. Journal of Clinical Microbiology, 41(2), 803-809. doi: $10.1128 / \mathrm{jcm} .41 .2 .803-809.2003$

Biuk-Rudan, N., Cvetníc, S., Madić, J., \& Rudan, D. (1999). Prevalence of antibodies to IBR and BVD viruses in dairy cows with reproductive disorders. Theriogenology, 51(5), 875-881. doi: 10.1016/ S0093-691X(99)00034-5

Bolin, S. R. (2002). Bovine viral diarrhea virus in mixed infection. Washington: ASM Press. Recuperado de https://www.ncbi.nlm.nih.gov/books/NBK2491/

Brewoo, J. N., Haase, C. J., Sharp, P., \& Schultz, R. D. (2007). Leukocyte profile of cattle persistently infected with bovine viral diarrhea virus. Veterinary Immunology and Immunopathology, 115(3-4), 369374. doi: 10.1016/j.vetimm.2006.10.011

Candela, M. G., Serrano, E., Martinez-Carrasco, C., Martín-Atance, P., Cubero, M. J., Alonso, F., \& Leon, L. (2009). Coinfection is an important factor in epidemiological studies: The first serosurvey of the aoudad (Ammotragus lervia). European Journal of Clinical Microbiology \& Infectious Diseases: Official Publication of the European Society of Clinical Microbiology, 28(5), 481-489. doi: 10.1007/ s10096-008-0654-8

Castro, R. S., Leite, R. C., Abreu, J. J., Lage, A. P., Ferraz, I. B., Lobato, Z. I., \& Balsamão, S. L. (1992). Prevalence of antibodies to selected viruses in bovine embryo donors and recipients from Brazil, and its implications in international embryo trade. Tropical Animal Health and Production, 24(3), 173-176. doi: 10.1007/BF02359611

Chiareli, D., Cosate, M. R. V., Moreira, E. C., Leite, R. C., Lobato, F. C. F., Silva, J. A. da,... Marcelino, A. P. (2012). Controle da leptospirose em bovinos de leite com vacina autógena em Santo Antônio do Monte, Minas Gerais. Pesquisa Veterinária Brasileira, 32(7), 633-639. doi: 10.1590/S0100736X2012000700008

Cole, J. R., Jr., Sulzer, C. R., \& Pursell, A. R. (1973). Improved microtechnique for the leptospiral microscopic agglutination test. Applied Microbiology, 25(6), 976-980.

Cortez, A., Castro, A. M. G., Heinemann, M. B., Soares, R. M., Leite, R. C., Scarcelli, E.,... Richtzenhain, L. J. (2006). Detecção de ácidos nucléicos de Brucella spp., Leptospira spp., herpesvirus bovino e vírus da diarréia viral bovina, em fetos bovinos abortados e em animais mortos no perinatal. Arquivo Brasileiro de Medicina Veterinária e Zootecnia, 58(6), 12261228. doi: 10.1590/S0102-09352006000600036

Costa, J. R. R., Lobato, Z. I. P., Herrmann, G. P., Leite, R. C., \& Haddad, J. P. A. (2006). Bluetongue virus antibodies in cattle and sheep in Southwest and Southeast regions of Rio Grande do Sul, Brazil. Arquivo Brasileiro de Medicina Veterinária e Zootecnia, 58(2), 273-275. doi: 10.1590/S010209352006000200017

Cowley, D. J. B., Clegg, T. A., Doherty, M. L., \& More, S. J. (2012). Bovine viral diarrhoea virus seroprevalence and vaccination usage in dairy and beef herds in the Republic of Ireland. Irish Veterinary Journal, 65(16), 1-9. doi: 10.1186/2046-0481-65-16

Empresa de Assistência Técnica e Extensão Rural de Minas Gerais. (2014). Perfil da agricultura familiar de Minas Gerais. Recuperado de http:// www.agricultura.mg.gov.br/ajuda/page/41-perfil-daagricultura-familiar-de-minas-gerais

Ferreira, J. S., Neto, Silveira, G. B. da, Rosa, B. M., Gonçalves, V. S. P., Grisi-, J. H. H., F ${ }^{o}$, Amaku, 
M.,... Lage, A. P. (2016). Avaliação de 15 anos do Programa Nacional de Controle e Erradicação da Brucelose e Tuberculose, Brasil. Semina: Ciências Agrárias, 37(5), 3385-3402. doi: 10.5433/1679-0359.2016v37n5Supl2p3385

Freitas, E. J. P., Lopes, C. E. R., Moura, J. M. de F ${ }^{\circ}$, Sá, J. S., Santos, H. P., \& Pereira, H. de M. (2014). Frequência de anticorpos contra o herpesvírus bovino tipo 1 (BoHV-1) em bovinos de corte não vacinados. Semina: Ciências Agrárias, 35(3), 1301-1310. doi: 10.5433/1679-0359.2014v35n3p1301

Greenacre, M. (2005). From correspondence analysis to multiple and joint correspondence analysis. doi: $10.2139 /$ ssrn.847664

Hosmer, D. W., \& Lemeshow, S. (2000). Applied logistic regression. New York: John Wiley \& Sons.

Instituto Brasileiro de Geografia e Estatística. (2006). Censo Agropecuário 2006: Agricultura Familiar - Primeiros Resultados. Recuperado de https:// biblioteca.ibge.gov.br/pt/biblioteca-catalogo? view= detalhes\&id=261914

Laender, J. O., Ribeiro, E. S., Gouveia, A. M. G., Lobato, Z. I. P., \& Felippe-Bauer, M. L. (2004). Levantamento das espécies de Culicoides latreille, 1809 (diptera: Ceratopogonidae) encontradas nas mesorregiões Norte de Minas, Jequitinhonha e Vale do Mucuri, Minas Gerais, Brasil. Entomol Vectores, 11(1), 145-157.

Lage, A. P., Herrmann, G. P., Moreira, É. C., Leite, R., Leite, Thompson, J. A.,... Gonçalves, V. S. P. (2007). Serology for Leptospira sp. in cattle of the State of Paraíba, Brazil. Arquivos do Instituto Biológico, São Paulo, 74(3), 185-190.

Lewis, F. I., \& Torgerson, P. R. (2012). A tutorial in estimating the prevalence of disease in humans and animals in the absence of a gold standard diagnostic. Emerging Themes in Epidemiology, 9(9), 1-8. doi: 10.1186/1742-7622-9-9

Lobato, Z. I. P., Guedes, M. I. M. C., \& Matos, A. C. D. (2015). Bluetongue and other orbiviruses in South America: Gaps and challenges. Veterinaria Italiana, 51(4), 253-262. doi: 10.12834/VetIt.600.2892.1

Menezes, I. R., Almeida, A. C. de, Pinto, M. S., Velasco, F. O., Maia, F. P., \& Rodrigues, G. V. (2014). Caracterização de unidades agrícolas familiares produtoras de leite no Norte do Estado de Minas Gerais. Revista do Instituto de Laticínios Cândido Tostes, 69(3), 153-163. doi: 10.14295/2238-6416. v69i3.342
Ministério da Agricultura, Pecuária e Abastecimento. (2006). Programa Nacional de Controle $e$ Erradicação da Brucelose e da Tuberculose Animal (PNCEBT). Brasília: MAPA.

Nielsen, K. (2002). Diagnosis of brucellosis by serology. Veterinary Microbiology, 90(1-4), 447-459. doi: 10.1016/S0378-1135(02)00229-8

Nikbakht, G., Tabatabaei, S., Lotfollahzadeh, S., Fasaei, B. N., Bahonar, A., \& Khormali, M. (2015). Seroprevalence of bovine viral diarrhoea virus, bovine herpesvirus 1 and bovine leukaemia virus in Iranian cattle and associations among studied agents. Journal of Applied Animal Research, 43(1), 22-25. doi: 10.1080/09712119.2014.883995

Okuda, L. H., Aguiar, D. M., Cavalcante, G. T., Stefano, E., Del Fava, C., Pituco, E. M.,... Gennari, S. M. (2006). Inquérito soro-epidemiológico do herpesvírus bovino tipo 1 (BoHV-1) no município de Monte Negro, Estado de Rondônia, Brasil. $O$ Biológico, 68(Supl.), 157-159.

Oliveira, L. F. (2016). Situação epidemiológica da brucelose bovina e caracterização da pecuária bovina no estado de Minas Gerais, 2011. Tese de Doutorado, Universidade Federal de Minas Gerais, Belo Horizonte, MG, Brasil. Recuperado de http:// www.bibliotecadigital.ufmg.br/dspace/handle/1843/ SMOC-AKFQBW

Oliveira, L. F., Dorneles, E. M. S., Mota, A. L. A. de A., Gonçalves, V. S. P., Neto, J. S. F., Ferreira, F.,... Lage, A. P. (2016). Soroprevalência e fatores de risco para brucelose bovina no Estado de Minas Gerais, Brasil. Semina: Ciências Agrárias, 37(5), 3449-3466. doi: 10.5433/1679-0359.2016v37n5Sup12p3449

Oliveira, R. M., Silva, M. L. C. R., Macêdo, M. M. S., Higino, S. S. dos S., Paulin, L. M., Alves, C. J.,... Azevedo, S. S. de. (2013). Soroepidemiologia da leptospirose e brucelose bovina em propriedades rurais de agricultura familiar do agreste paraibano, Nordeste do Brasil. Arquivos do Instituto Biológico, 80(3), 303-311. doi: 10.1590/S180816572013000300007

Pearson, J. E., \& Jochim, M. M. (1979, oct.). Protocol for the immunodiffusion test for bluetongue. Proceedings of Annual Meeting American Association of Veterinary Laboratory Diagnosticians, San Diego, California, USA, 22. Retrieved from https://www. aavld.org/

Petrakovsky, J., Bianchi, A., Fisun, H., Nájera-Aguilar, P., \& Pereira, M. M. (2014). Animal leptospirosis in Latin America and the Caribbean countries: 
Reported outbreaks and literature review (20022014). International Journal of Environmental Research and Public Health, 11(10), 10770-10789. doi: 10.3390/ijerph111010770

Pinto, P. S., Loureiro, A. P., Penna, B., \& Lilenbaum, W. (2015). Usage of Leptospira spp. local strains as antigens increases the sensitivity of the serodiagnosis of bovine leptospirosis. Acta Tropica, 149, 163-167. doi: 10.1016/j.actatropica.2015.05.008

Potgieter, L. N. (1995). Immunology of bovine viral diarrhea virus. The Veterinary Clinics of North America. Food Animal Practice, 11(3), 501-520. doi: 10.1016/S0749-0720(15)30464-3

Rêgo, M. J. P., Batista, A. F. B., Fo, Oliveira, P. R. F. de, Borges, J. de M., França, C. A. B. de, Ribeiro, C. P., ... Pinheiro, J. W., Jr. (2016). Análise epidemiológica da infecção pelo vírus da diarreia viral bovina em rebanhos da agricultura familiar, Brasil. Semina: Ciências Agrárias, 37(6), 41194130. doi: 10.5433/1679-0359.2016v37n6p4119

Richtzenhain, L. J., Barbarini, O., Umehara, O., De Gracia, A. S., Cortez, A., Heinemann, M. B., \& Ferreira, F. (1999a). Rinotraqueíte infecciosa bovina: Levantamento sorológico nos Estados de Minas Gerais, Mato Grosso do Sul, São Paulo, Rio de Janeiro, Paraná e Rio Grande do Sul. Arquivos do Instituto Biológico, 66(1), 83-88.

Richtzenhain, L. J., Barbarini, O., Umehara, O., De Gracia, A. S., Cortez, A., Heinemann, M. B.,... Soares, R. M. (1999b). Diarréia viral bovina: Levantamento sorológico nos estados de Minas Gerais, Mato Grosso do Sul, São Paulo, Rio de Janeiro, Paraná e Rio Grande do Sul. Arquivos do Instituto Biológico, 66(1), 107-111.

Sá, A., Jr., Carvalho, L. G., Silva, F. F., \& Alves, M. C. (2012). Application of the Köppen classification for climatic zoning in the state of Minas Gerais, Brazil. Theoretical and Applied Climatology, 108(1-2), 1-7. doi: 10.1007/s00704-011-0507-8

Sanderson, M. W., \& Gnad, D. P. (2002). Biosecurity for reproductive diseases. The Veterinary Clinics of North America. Food Animal Practice, 18(1), 79-98. doi: 10.1016/S0749-0720(02)00003-8

Silva, T. M.A. da, Oliveira, R. G. de, Mol, J.P. da S., Xavier, M. N., Paixão, T. A. da, Cortez, A.,... Santos, R. de L. (2009). Etiologic diagnosis of bovine infectious abortion by PCR. Ciência Rural, 39(9), 2563-2570. doi: 10.1590/S0103-84782009000900028
Smith, R. D. (1990). Veterinary clinical epidemiology: A problem oriented approach. Stoneham: ButterworthHeinemann.

Stevenson, M., Nunes, T., Heuer, C., Marshall, J., Sanchez, J., Thornton, R.,... Jay, M. (2017). EpiR: Tools for the analysis of epidemiological data ( $\mathrm{R}$ package version 0.9-91). Recuperado de https:// cran.r-project.org/web/packages/epiR/index.html

Thompson, J. A., de Miranda Henriques Leite, R., Gonçalves, V. S. P., Leite, R. C., Bandeira, D. A., Herrmann, G. P., . . . Lage, A. P. (2006). Spatial hierarchical variances and age covariances for seroprevalence to Leptospira interrogans serovar hardjo, BoHV-1 and BVDV for cattle in the State of Paraíba, Brazil. Preventive Veterinary Medicine, 76(34), 290-301. doi: 10.1016/j.prevetmed.2006.05.010

Tomich, R. G. P., Serra, C. V., Bomfim, M. R. Q., Campos, F. S., Lobato, Z. I. P., Pellegrin, A. O.,... Barbosa-Stancioli, E. F. (2009). Sorodiagnóstico de doenças da reprodução em rebanhos de bovinos leiteiros de assentamentos rurais de Corumbá, MS. Arquivo Brasileiro de Medicina Veterinária e Zootecnia, 61(4), 986-991. doi: 10.1590/S010209352009000400029

Vasconcellos, S. A., Barbarini, O., Jr., Umehara, O., Morais, Z. M. de, Cortez, A., Pinheiro, S. R.,... Ferreira, J. S., Neto (1997). Leptospirose bovina. Níveis de ocorrência e sorotipos predominantes em rebanhos dos Estados de Minas Gerais, São Paulo, Rio de Janeiro, Paraná, Rio Grande do Sul e Mato Grosso do Sul. Período de janeiro a abril de 1996. Arquivos do Instituto Biológico, 64(2), 7-15.

World Organization for Animal Health. (2015). Bovine viral diarrhoea. In Manual of Diagnostic Tests and Vaccines for Terrestrial Animals (Chap. 3.4.7, pp. 1075-1096). Paris. OIE. Recuperado de http://www. oie.int/en/standard-setting/terrestrial-manual/accessonline/

World Organization for Animal Health. (2017). Infectious bovine rhinotracheitis/infectious pustular vulvovaginitis. In Manual of Diagnostic Tests and Vaccines for Terrestrial Animals (Chap. 3.4.11, pp. 1139-1157). Paris. OIE. Recuperado de http://www. oie.int/en/standard-setting/terrestrial-manual/accessonline/

Zar, J. H. (1996). Bioestatistical analysis (3th ed). New Jersey: Prentice Hall. 